
СУЛЬФАТУ НА НЕВРОЛОГІЧНИЙ ДЕФІЦИТ ТА МНЕСТИЧНІ ФУНКЦЇ̈ У ЩУРІВ ІЗ МОДЕЛЛЮ ЧЕРЕПНО-МОЗКОВОЇ ТРАВМИ

\title{
С.І. Семененко
}

Вінницький національний медичний університет ім. М.І. Пирогова, м.Вінниця, Україна

\section{Ключові слова:}

черепно-мозкова травма, адемол, амантадину сульфат, магнію сульфат, неврологічний дефіцит, мнестичні функиії.

Буковинський медичний вісник. T.23, № 4 (92).

C. $108-115$.

\section{DOI:}

10.24061/2413-0737.

XXIV.4.92.2019.97

E-mail:semenenkos1@ rambler.ru
Мета роботи - порівняти вплив похідної адамантану 1-адамантилетилокси-3-морфоліно-2-пропанолу гідрохлориду (адемолу), амантадину сульфату та магнію сульфату на неврологічний дефіиит та мнестичні функиії у щурів із моделлю черепно-мозкової травми.

Матеріал і методи. Вилив адемолу на експериментальній моделі черепно-мозкової травми оцінювали при застосуванні 2 мг/кг внутрішньовенно. Псевдооперованим тваринам уводили внутрішньовенно 0,9\% розчин хлориду натрію в об 'ємному співвідношенні 2 мл/кг. Як лікарський засіб для контрольної групи застосовували $0,9 \%$ розчин хлориду натрію в дозі 2 мл/кг внутрішньовенно. Як препарати порівняння використовували магнію сульфат (250 мг/мл) 250 мг/кг внутрішньовенно та амантадину сульфат (200 мг/500 мл) 5 мг/кг внутрішньовенно. Неврологічний дефічит у щурів із черепно-мозковою травмою оцінювали на першу та восьму доби за шкалою stroke-index C.P. McGrow. Здатність тварин до запам'ятовування аверсивного стимулу досліджували в тесті умовної реакиії пасивного уникання. Збереження умовної реакиї̈ перевіряли через добу за зміною латентного часу входу шура до темного відсіку.

Результати. Досліджсючи вплив розчину адемолу на ступінь деескалачії неврологічного дефіциту, можна зазначити, що даний препарат переважав препарати порівняння амантадину сульфат та магнію сульфату на першу добу застосування на 10\% та 24\% та на восьму добу на 17\% та 30\%, відповідно, при иьому середній бал за шкалою С. P. McGrow у гру-

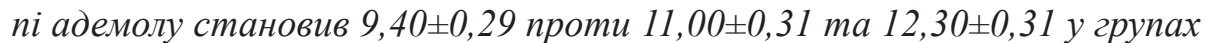
порівняння. Щодо відновлення мнестичних функиій при черепно-мозковій травмі, восьмиденна терапія щурів розчинами амантадину сульфату та магнію сульфату певною мірою покрашувала функиію запам'ятовування, але поступалась за ефективністю адемолу, який наближав показники тесту умовної реакиії пасивного уникання до аналогічних у псевдооперованих тварин.

Висновки. Проведене експерементальне дослідження продемонструвало, щуо у шурів із тяжкою черепно-мозковою травмою спостерігались тяжский неврологічний дефіцит, погіршення процесів навчання $і$ пам'яті у відновному періоді. Адемол істотніше, відносно амантадину сульфату та магнію сульфату, впливав на деескалацію неврологічних порущень, щуо супроводжувалося покращенням мнестичних функиій у тварин із черепно-мозковою травмою.

\footnotetext{
Ключевые слова:

черепно-мозговая травма, адемол, амантадина сульфат, магния сульфат, неврологический дефииит, мнестические функции.
}

СРАВНИТЕЛЬНОЕ ВЛИЯНИЕ АДЕМОЛА, АМАНТАДИНА СУЛЬФАТА, МАГНИЯ СУЛЬФАТА НА НЕВРОЛОГИЧЕСКИЙ ДЕФИЦИТ И МНЕСТИЧЕСКИЕ ФУНКЦИИ У КРЫС С МОДЕЛЬЮ ЧЕРЕПНО-МОЗГОВОЙ ТРАВМЫ

С.И. Семененко

Цель работы - сравнить влияние производной адамантана 1-адамантилетилоксы-3-морфолино-2-пропанола гидрохлорида (адемола), амантадина сульфата и магния сульфата на неврологический дефицит и мнестические 
Original research

Буковинский медищинский вестник. T.23, № 4 (92). C. 108-115.

функиии у крыс с моделью черепно-мозговой травмы.

Материал и методы. Влияние адемола на экспериментальной модели черепно-мозговой травмы оченивали при использовании 2 мг/кг. Псевдооперированным животным вводили внутривенно 0,9\% раствор хлорида натрия в объемном соотношении 2 мл/кг. В качестве лекарственного средства для контрольной группы применяли $0,9 \%$ раствор хлорида натрия в дозе $2 \mathrm{мл/кг.} \mathrm{В} \mathrm{качестве} \mathrm{препаратов} \mathrm{сравнения} \mathrm{использовали} \mathrm{магния}$ сульфат (250 мг/мл) 250 мг/кг и амантадина сульфат (200 мг/500 мл) 5 мг/кг. Неврологический дефицит у крыс с черепно-мозговой травмой оценивали на первые и восьмые сутки по шкале stroke-index C.P. McGrow. Способность животных к запоминанию аверсивного стимула исследовали в тесте условной реакиии пассивного избегания. Сохранение условной реакции проверяли через сутки по изменению латентного времени входа крысы в темный отсек.

Результаты. Исследуя влияние раствора адемола на степень деэскалации неврологического дефицита, можно отметить, что данный препарат восходил препараты сравнения амантадина сульфата и магния сульфата в первые сутки применения на $10 \%$ и 24\% и на восьмые сутки на $17 \%$ и $30 \%$ соответственно, при этом средний балл по шкале C. P.oMcGrow в группе

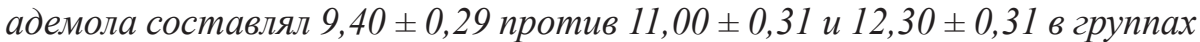
сравнения. По восстановлению мнестических функций при черепно-мозговой травме восьмидневная терапия крыс растворами амантадина сульфата и магния сульфата в определенной степени улучшала функиию запоминания, но уступала по эффективности адемолу, который приближал показатели теста условной реакиии пассивного избегания к аналогичным у псевдооперированных животных.

Выводы. Проведенное экспериментальное исследование показало, что у крыс с тяжелой черепно-мозговой травмой наблюдались тяжелый неврологический дефичит, ухудтение прочессов обучения и памяти в восстановительном периоде. Адемол существенно, относительно амантадина сульфата и магния сульфата, влиял на деэскалаџию неврологических нарушений, что сопровождалось улучшением мнестических функиий у животных с черепно-мозговой травмой.

Keywords: traumatic brain injury, ademol, amantadine sulfate, magnesium sulfate, neurological deficiency, mnemonic functions.

Bukovinian Medical Herald. V.23, № 4 (92). P. 108-115.

\section{COMPARATIVE INFLUENCE OF ADEMOL, AMANTADINE SULFATE, SULFATE MAGNESIUM ON NEUROLOGIC DEFICIT AND MNEMONIC FUNCTIONS OF RATS WITH A TRAUMATIC BRAIN INJURY MODEL}

\section{S.I. Semenenko}

Objective. To compare the effects of adamantane derivative 1-adamantylethyloxy-3-morpholino-2-propanol hydrochloride (ademole), amantadine sulfate and magnesium sulfate on neurological deficits and mnemonic functions in rats with a model of craniocerebral trauma.

Material and methods. The effect of ademole on the experimental model of cranial trauma was evaluated at $2 \mathrm{mg} / \mathrm{kg}$ intravenously. Pseudo-operated animals were injected intravenously with a $0.9 \%$ solution of sodium chloride in a volume ratio of $2 \mathrm{ml} / \mathrm{kg}$. As a drug for the control group, $0.9 \%$ sodium chloride solution at a dose of $2 \mathrm{ml} / \mathrm{kg}$ intravenously was used. Magnesium sulfate $(250 \mathrm{mg} / \mathrm{ml}) 250 \mathrm{mg} / \mathrm{kg}$ intravenously and amantadine sulfate $(200 \mathrm{mg} / 500 \mathrm{ml})$ $5 \mathrm{mg} / \mathrm{kg}$ intravenously were used as comparative drugs. Neurological deficits in rats with craniocerebral trauma were evaluated on the first and eighth day in the stroke-index C.P. McGrow. The ability of animals to memorize the aversive stimulus was investigated in the test of the conditional reaction of passive 
avoidance. The preservation of the conditioned reaction was checked a day after changing the latent time of the rat's entrance to the dark compartment.

Results. Investigating the effect of adamole solution on the degree of de-inclination of the neurological deficiency, it can be noted that the drug was dominated by comparisons of amantadine sulfate and magnesium sulfate on the first day of application by $10 \%$ and $24 \%$ and on the eighth day by $17 \%$ and $30 \%$ respectively, with the average score on the scale of SR McGrow in the ademole group was $9.40 \pm 0.29$ versus $11.00 \pm 0.31$ and $12.30 \pm 0.31$ in the comparison groups. Regarding the restoration of mnemonic functions in the craniocerebral trauma, eight-day therapy of rats with solutions of amantadine sulfate and magnesium sulfate somewhat improved the memory function, but inferior to the effectiveness of ademole, which approximated the test results of the conditional reaction of passive avoidance to similar in pseudo-controlled animals.

Conclusions. An experimental study conducted showed that severe neurological deficits, worsening learning and memory in the recovery period occurred in rats with severe craniocerebral trauma. Ademol significantly, compared to amantadine sulfate and magnesium sulfate significantly, affected deascalation of neurological disorders, which was accompanied by improved mnemonic functions in animals with craniocerebral trauma.

Вступ. У зв’язку з війною на Сході України в останні роки визначається значне зростання як загального травматизму загалом, так і мозкового травматизму зокрема [1]. Пошук та розробка нових фармакологічних молекул, котрі здатні покращити ведення цієї складної когорти пацієнтів, потребує глибокого вивчення всіх патофізіологічних каскадів мозкового пошкодження, проведення доклінічних та клінічних досліджень у цьому напрямку. Патофізіологічними механізмами вторинного пошкодження мозку при ЧМТ є еволюційно вироблені каскадні біохімічні стресові реакції, які індукуються у відповідь на первинне ушкодження і розвиваються 3 плином часу. Гостра ексайтотоксична нейродегенерація, зумовлена надмірною активацією NMDA-рецепторів та патологічними реакціями глутамат-кальцієвого ушкодження, розвивається не лише при мозкових інсультах, доведеним на сьогоднішній день, є іiі визначальна роль в ініціації вторинних пошкоджень при травматичних ураженнях головного мозку [2]. Амантадину сульфат і магнію сульфат є речовинами 3 низькою спорідненістю до NMDA-рецепторів, тому саме на дослідження цих молекул протягом останніх років були направлені зусилля нейрофармакологів. Терапевтичний ефект амантадину сульфату носить комплексний характер і заснований на: блокуванні NMDA-рецепторів глутамату, підвищенні синтезу дофаміну в нігральних нейронах, посиленні вивільнення дофамінових везикул у синаптичну щілину і блокуванні зворотного захоплення дофаміну в пресинаптичні термінали, м'якій холіноблокуючій дії [3]. Вартий уваги той факт, що результати останніх досліджень спростовують наявність позитивного впливу амантадину сульфату на пізнавальні функції головного мозку. У 2018 році американськими дослідниками F. M. Hammond, M. Sherer, J. F. Malec et al. у мультицентровому рандомізованому плацебо-контрольованому дослідженні доведено відсутність впливу амантадину сульфату на когнітивні функції у пацієнтів з черепно-мозковою травмою (ЧМТ) [4]. Проте неоднорідність отриманих результатів вказує лише на перспективу в подальшому дослідженні даного препарату. Магнію сульфат вирізняється серед антагоністів NMDA-рецепторів своєю безпекою й тривалою історією клінічного застосування. Встановлено, що іони $\mathrm{Mg} 2+$ блокують NMDA-асоційовані канали потенціалзалежним способом і, вступаючи 3 глутаматом у неконкурентний антагонізм, пригнічують його вивільнення, гальмуючи ексайтотоксичність [5]. Нашу зацікавленість викликав опублікований I. Lingam, N. J. Robertson y 2018 році ретельний літературний огляд всіх вдалих та провальних досліджень застосування магнію сульфату в нейропрактиці [6]. Вчені дійшли висновку, що потрібні подальші дослідження даного препарату, дослідження, які б розкрили науці додаткові можливості його призначення, а призначення сульфату магнію при ЧМТ на сьогоднішньому етапі продовжують залишатись предметом наукових дискусій [6].

Таким чином, клінічні дослідження нейропротекторів - антагоністів NMDA-рецепторів, амантадину сульфату та магнію сульфату, потребують додаткового більш детального вивчення. Перспективною для подальшого вивчення $є$ сполука, яка володіє нейропротекторними властивостями, синтезована під керівництвом акад. М. О. Лозинського в Інституті органічної хімії НАН України, похідна адамантану 1-адамантилетилокси-3-морфоліно-2-пропанолу гідрохлорид (лабораторний шифр ЮК-1, умовна назва адемол). Нейропротекторна дія адемолу пов'язана з модулюючим впливом на активність NMDA-рецепторів, усуненням енергодефіциту, метаболічного ацидозу, оксидативного ушкодження нейронів, нормалізуючим впливом на обмін монооксиду азоту, нормалізацією мозкового кровоплину, збереженням цитоархітектоніки кори мозку, 
у тому числі, за рахунок зменшення апоптозу [7]. На основі проведених досліджень можна стверджувати, що препарат володіє комплексним впливом, проявляючи властивості як первинного, так і вторинного церебропротектора $[8,9]$.

Мета роботи. Порівняти вплив похідної адамантану 1-адамантилетилокси-3-морфоліно-2-пропанолу гідрохлориду (адемолу), амантадину сульфату та магнію сульфату на неврологічний дефіцит та мнестичні функції у щурів із моделлю черепно-мозкової травми.

Матеріал і методи. Експерименти проведено на білих щурах-самцях масою 160-190 г, які перебували у стандартних умовах віварію, з дотриманням етичних но 3 “Загальними принципами роботи на тваринах", затвердженими I Національним конгресом з біоетики (Київ, Україна, 2001) та Законом України “Про захист тварин від жорстокого поводження” від 26.02.2006 року. Експериментальну модель ЧМТ викликали дією потоку вуглекислого газу під тиском, що створювали із використанням газобалонного пневматичного пістолета марки «Байкал МР-654 К» (РФ, Іжевськ, № сертифіката POCC RU MЖ03.B02518) та балонів вуглекислого газу (маса зрідженого CO2-12 г) під тиском (Crosman, США, № серії 456739). Щурам в умовах пропофолового наркозу (60 мг/кг), після катетеризації стегнової вени та налагодження можливості здійснювати інфузію через інфузомат, здійснювали правобічну кістково-пластичну норм проведення експериментальних досліджень згід-

трепанацію черепа в проекції середньої мозкової артерії, 3 діаметром отвору 5 мм². Після фіксації щура в положенні на животі вниз головою здійснювали постріл 3 фіксованої відстані (постріл впритул), кістковий фрагмент на окісті разом із апоневрозом, повертали на місце і рану зашивали пошарово. Таким чином моделювалася ЧМТ тяжкого ступеня.

Терапевтичну дію Адемолу («Адемол-Дарниця», Дарниця, Україна, 10 ампул по 5 мл концентрацією 1 мг/мл) на експерементальній ЧМТ оцінювали при застосуванні дози 2 мг/кг в/в. Лікування відбувалось шляхом повільної в/в інфузії інфузоматом, яка тривала 2 год з інтервалом через кожні 12 год (2 рази/добу) упродовж восьми діб. Лікування розпочинали через 1 год після моделювання патологічного стану. Як препарати порівняння використовували Магнію сульфат («Магній сульфат-Дарниця», Дарниця, Україна, 250 мг/мл) 250 мг/кг в/в та Амантадину сульфат («ПК-Мерц», Merz Pharmaceuticals, Швейцарія, 200 мг/500 мл) 5 мг/кг в/в у такому ж режимі.

Псевдооперованих тварин піддавали всім втручанням (наркоз, розріз шкіри, кістково-пластична трепанація черепа) за виключенням маніпуляцій, які безпосередньо могли б призвести до травматичного ураження мозку, що нівелювало вплив травматичних умов експерименту. Їм також вводили еквівалентну в об'ємному співвідношенні до адемолу, кількість, 0,9\% розчину $\mathrm{NaCI}$. Як лікарський засіб для контрольної

Таблиця 1

Вплив адемолу, амантадину сульфату та магнію сульфату на неврологічний дефіцит у щурів із черепно-мозковою травмою після курсового введення (8 днів) $(\mathrm{M} \pm \mathrm{m}, \mathrm{n}=10)$

\begin{tabular}{|c|c|c|}
\hline \multirow[t]{2}{*}{ Група щурів } & \multicolumn{2}{|c|}{$\begin{array}{c}\text { Неврологічний дефіцит за шкалою } \\
\text { C.P. McGrow }\end{array}$} \\
\hline & 1-ша доба & 8-ма доба \\
\hline Псевдооперовані щури+ 0,9\% розчин $\mathrm{NaCl}$ & $0,30 \pm 0,25$ & $0,00 \pm 0,00$ \\
\hline $\begin{array}{c}\mathrm{ЧMT}+0,9 \% \text { розчин } \mathrm{NaCl} \text { (контрольна } \\
\text { патологія) }\end{array}$ & $16,25 \pm 0,25$ & $15,80 \pm 0,62$ \\
\hline $\begin{array}{l}\text { ЧМТ + адемол, } \\
2 \text { мг/кг в/в }\end{array}$ & $12,30 \pm 0,23^{\circ * \bullet}$ & $9,40 \pm 0,29^{\circ * \# \bullet}$ \\
\hline $\begin{array}{c}\text { ЧМТ + } \\
\text { амантадину сульфат, } \\
5 \text { мг/кг в/в }\end{array}$ & $13,50 \pm 0,26^{\circ *}$ & $11,00 \pm 0,31^{\circ *}$ \\
\hline $\begin{array}{c}\text { ЧМТ + магнію сульфат, } \\
250 \text { мг/кг в/в }\end{array}$ & $15,33 \pm 0,30^{\circ} *$ & $12,30 \pm 0,31^{\mathrm{o} *}$ \\
\hline
\end{tabular}

\section{Примітки:}

1. ЧМТ - черепно-мозкова травма;

2. ${ }^{\circ}-\mathrm{p}<0,05$ відносно псевдооперованих щурів;

3. * - $<<0,05$ відносно групи контрольної патології;

4. \# - $\mathrm{p}<0,05$ відносно групи, що отримувала

амантадину сультат (5 мг/кг в/в);

5. • - $<<0,05$ відносно групи, що отримувала магнію

сульфату (250 мг/кг в/в). 
групи (щури з ЧМТ) застосовували $0,9 \%$ розчин $\mathrm{NaCI}$ у дозі 2 мл/кг в/в у тому ж режимі.

Неврологічний дефіцит у щурів із ЧМТ тяжкого ступеня (так само як і інші функціональні та лабораторні показники) оцінювали на першу добу та наприкінці гострого періоду через 12 год після останнього введення препаратів (на 8-му добу) за шкалою stroke-index C.P. McGrow [10]. Тяжкість стану визначали за сумою відповідних балів: до 3 балів - легкий ступінь, від 3 до 7 балів - середній ступінь, вище 7 балів — тяжкий ступінь.

Здатність тварин до навчання та запам'ятовування аверсивного стимулу досліджували в аналогічний період (8-ма доба) ЧМТ у тесті умовної реакції пасивного уникання (УРПУ). Методика заснована на природженому інстинкті щурів до обмеженого затемненого простору. Збереження УРПУ перевіряли через добу за зміною латентного часу входу щура до темного відсіку.

Кількісні дані обробляли за допомогою програми статистичної обробки StatPlus 2009. Використовували параметричний критерій t Стьюдента у випадках нормального розподілу варіаційного ряду, непараметричний критерій W. Уайта - за його відсутності, парний критерій Т. Вілкоксона — для визначення змін у динаміці всередині групи, кутове перетворення Фішера [11] — при обліку результатів в альтернативній формі (наявність або відсутність певної ознаки). Відмінності вважали статистично значущими при $\mathrm{p}<0,05$.

\section{Результати дослідження та їх обговорення}

Одним із маркерів ефективності нейропротектора $€$ його позитивний вплив на психоневрологічну симптоматику. У запланованому нами дослідженні порівнювались властивості інтенсивної терапії ЧМТ адемолом у дозі 2 мг/кг в/в стосовно редукції неврологічного дефіциту у щурів порівняно з розчинами амантадину сульфату та магнію сульфату, що у ряді досліджень продемонстрували позитивний вплив на перебіг мозкового травматизму, проте за результатами огляду літератури потребують подальшого вивчення (табл. 1).

Проведене дослідження показало, що як і наприкінці першої доби ЧМТ, так і через вісім діб після моделювання патології, у щурів мали місце тяжкі неврологічні зміни: судоми, паралічі, парези та птоз, які в групі контрольної патології не зникали повністю. Однак за балами, за шкалою C.P. McGrow, неврологічний дефіцит у щурів із ЧМТ тяжкого ступеня, що отримували лише $0,9 \%$ розчин $\mathrm{NaCl}$, на 24 год після отримання травми $\epsilon$ співвідносним із таким, що мав місце на 8-му добу, та достеменно не відрізнявся. Так, щурам, яким як терапію ЧМТ уводили лише $0,9 \%$ розчин $\mathrm{NaCl}$ (контрольна патологія), середній бал за шкалою С. P. McGrow

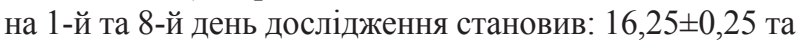

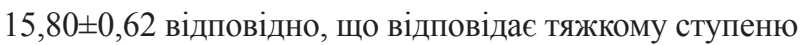
неврологічної симптоматики. Варто зазначити, що

Таблиця 2

Вплив адемолу, амантадину сульфату та магнію сульфату на навчання та пам'ять щурів із черепно-мозковою травмою за тестом умовної реакції пасивного уникнення після курсового введення (8 днів)

$(\mathbf{M} \pm \mathbf{m}, \mathbf{n}=\mathbf{1 0})$

\begin{tabular}{|c|c|c|}
\hline \multirow[b]{2}{*}{ Група щурів } & \multicolumn{2}{|c|}{ Латентний період входу в темну камеру, с } \\
\hline & до навчання & через 24 год після навчання \\
\hline $\begin{array}{l}\text { Псевдооперовані щури }+ \text { 0,9\% розчин } \\
\mathrm{NaCl}\end{array}$ & $5,30 \pm 0,42$ & $223,80 \pm 1,66$ \\
\hline $\begin{array}{c}\text { ЧМТ }+0,9 \% \text { розчин } \mathrm{NaCl} \text { (контрольна } \\
\text { патологія) }\end{array}$ & $\begin{array}{l}19,70 \pm 0,47^{\circ} \\
(+271,7 \%)\end{array}$ & $\begin{array}{c}48,90 \pm 0,96^{\circ} \\
(-78,2 \%)\end{array}$ \\
\hline $\begin{array}{l}\text { ЧМТ + адемол, } \\
2 \text { мг/кГ в/в }\end{array}$ & $\begin{array}{c}11,00 \pm 0,28^{\circ * \#} \bullet \\
(+107,5 \%) \\
{[-44,7 \%]} \\
\end{array}$ & $\begin{array}{c}98,80 \pm 2,50 \% * \bullet \\
(-55,7 \%) \\
{[+102,0 \%]} \\
\end{array}$ \\
\hline $\begin{array}{c}\text { ЧМТ + } \\
\text { амантадину сульфат, } \\
5 \text { мг/кг в/в } \\
\end{array}$ & $\begin{array}{c}13,70 \pm 0,35^{\circ *} \\
(+158,5 \%) \\
{[-30,5 \%]} \\
\end{array}$ & $\begin{array}{c}76,50 \pm 1,30^{\circ *} \\
(-65,7 \%) \\
{[+56,4 \%]} \\
\end{array}$ \\
\hline $\begin{array}{l}\text { ЧМТ + магнію сульфат, } \\
250 \text { мг/кг в/в }\end{array}$ & $\begin{array}{c}15,30 \pm 0,28^{\circ *} \\
(+188,7 \%) \\
{[-22,4 \%]}\end{array}$ & $\begin{array}{c}65,00 \pm 1,04^{\circ *} \\
(-70,9 \%) \\
{[+32,9 \%]}\end{array}$ \\
\hline
\end{tabular}

\section{Примітки:}

1. ЧМТ - черепно-мозкова травма;

2. $\quad{ }_{-}-\mathrm{p}<0,05$ відносно псевдооперованих щурів;

3. * - $<<0,05$ відносно групи контрольної патології;

4. \# - $<<0,05$ відносно групи, що отримувала амантадину сульфат (5 мг/кг в/в);

5. • - p<0,05 відносно групи, що отримувала магнію сульфат (250 мг/кг в/в);

6. У круглих дужках - зміни (\%) відносно показника псевдооперованих щурів, у квадратних дужках -

відносно показника щурів із ЧМТ, яким уводили 0,9 \% розчин $\mathrm{NaCl}$ (контрольна патологія). 
застосування $0,9 \%$ розчину $\mathrm{NaCl}$ протягом восьми діб не спричиняло зменшення неврологічного дефіциту в щурів з експериментальною ЧМТ.

Аналізуючи вплив курсової терапії розчином адемолу дозою 2 мг/кг в/в на ступінь деескалації неврологічного дефіциту, можна зазначити, що за цією властивістю досліджуваний препарат переважав препарати порівняння амантадину сульфату та магнію сульфату на першу добу застосування відповідно на 10\% та 24\%, при цьому по відношенню до магнію сульфату ця різниця була достовірною. Досліджуючи ефективність проведеної терапії ЧМТ на восьму добу спостереження, результати після застосування розчину адемолу продемонстрували зменшення неврологічного дефіциту ще більш динамічне, ніж на першу добу дослідження. Результати, отримані в щурів, яким вводили адемол, достовірно переважали аналогічні показники у групах із введенням розчинів амантадину сульфату на $17 \%$ та магнію сульфату на $30 \%$ — при цьому середній бал за шкалою

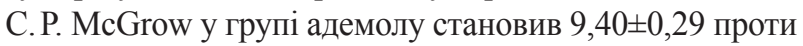
$11,00 \pm 0,31$ та $12,30 \pm 0,31$ у групах порівняння.

Здатність тварин до навчання та запам'ятовування аверсивного стимулу досліджували в аналогічний період (8-ма доба) ЧМТ у тесті умовної реакції пасивного уникання (УРПУ). Навчання щурів проводили в двокамерній установці, що складається 3 двох відсіків світлого та темного. Тварину вміщували до світлого відсіку, фіксували латентний час входу в темний відсік, де щур отримував подразнення електричним струмом та вибігав у світлий відсік. Збереження УРПУ перевіряли через добу за зміною латентного часу входу щура до темного відсіку.

Щодо відновлення мнестичних функцій при ЧМТ, восьмиденна терапія щурів розчинами амантадину сульфату та магнію сульфату дещо покращувала пам'ять, але поступалась за ефективністю адемолу, який краще наближав показники тесту УРПУ до результатів псевдооперованих щурів (табл. 2).

Так, латентний період УРПУ у щурів, що отримували адемол та референс-препарати (амантадину сульфат та магнію сульфат), достовірно покращився, відповідно, 11,0; 13,7 та 15,3 порівняно з контрольною групою 19,7. Отримані також цікаві результати щодо збільшення часу латентного періоду входу в темну камеру щурів після 24 годин з моменту аверсивного стимулу. Так, у групі щурів, котрим уводили адемол, час затримки входу в темну камеру достовірно перевищував аналогічний показник у групах щурів, котрим уводили магнію сульфат та амантадину сульфат, що вказує на істотніший позитивний вплив адемолу на здатність до запам'ятовування у щурів з ЧМТ (табл. 2).

Отже, у щурів із тяжкою ЧМТ спостерігались тяжкий неврологічний дефіцит, погіршення процесів навчання і пам'яті у відновному періоді. Адемол ліпше за препарати порівняння сприяв зменшенню виразності неврологічних порушень, що супроводжувалося покращенням мнестичних функцій у щурів із ЧМТ на 8-му добу.
Патогенетичним механізмом церебропротективного впливу адемолу на ішемізований головний мозок, зокрема і при ЧМТ, може бути низькоафінна неконкурентна блокада поліамінового сайту NMDA-рецепторів іонофорного комплексу пірамідних нейронів гіпокампа 3 дуже швидкою кінетикою деблокади NMDA-рецепторів [12]. Адемол, завдяки його здатності ініціювати перехід активованого NMDA-каналу в блоковану форму й назад, забезпечує зростання середньої тривалості потоків імпульсів, що дозволяє розглядати адемол скоріше як потенціатор, ніж блокатор канальних структур із швидкою блокадою/деблокадою NMDA-рецепторів. Такий модулюючий вплив адемолу на NMDA-рецептори може забезпечувати нормальне функціонування неушкодженої нервової тканини, селективно знижуючи лише надлишкову активацію NMDA-рецепторів [13]. Нейропротекторні ефекти адемолу, певною мірою, також пов'язані з наявністю стимулюючого впливу на кровопостачання головного мозку. У дослідженнях продемонстровано наявність у адемолу стимулюючої дії на мозковий кровоплин у басейні внутрішньої сонної артерії при гострому порушенні мозкового кровообігу за ішемічним типом [12]. У проведеному дослідженні введення адемолу щурам із гострим порушенням мозкового кровообігу зменшувало деструктивні зміни в нейронах головного мозку і сприяло відновленню порушених показників кислотно-лужної рівноваги [8]. Доведено, що введення адемолу за умов гострої церебральної ішемії корелювало з відновленням енергопостачання головного мозку (збільшення вмісту АТФ, малату та пірувату), зменшенням вмісту лактату та усуненням декомпенсованого метаболічного ацидозу, коректуючим впливом на активність синтази монооксиду азоту, зниженням інтенсивності пероксидного окиснення ліпідів і окисної модифікації білків, активацією ферментативної ланки антиоксидантного захисту мозку (супероксиддисмутази, каталази, глутатіонпероксидази) [9]. Також дослідження продемонстрували, що в постреперфузійному періоді гострої церебральної ішемії адемол зменшував інтенсивність фрагментації ДНК (маркеру нейроапоптозу) в ядрах кортикальних нейронів, що свідчить про його антиапоптотичні властивості [7].

Отже, адемол - препарат із мультимодальним патофізіологічним нейропротекторним механізмом діï, позитивні ефекти впливу якого на ішемізований головний мозок продемонстровані, зокрема, і в нашому дослідженні.

\section{Висновки}

1. Результати корекції неврологічних розладів, оцінені за шкалою C. P.0McGrow у групах щурів із експериментальною черепно-мозковою травмою, котрі отримували лікування адемолом, амантадином сульфатом та магнію сульфатом, мали достовірні переваги перед внутрішньовенним уведенням $0,9 \%$ розчину хлориду натрію.

2. Аналізуючи вплив розчину адемолу щурам із черепно-мозковою травмою на ступінь деескалації 
неврологічного дефіциту за шкалою C.P. McGrow, можна зазначити, що за цією властивістю досліджуваний препарат переважав препарати порівняння амантадину сульфату та магнію сульфату на першу добу застосування відповідно на 10\% та 24\%, при цьому по відношенню до магнію сульфату ця різниця була достовірною.

2. Порівнюючи ефективність адемолу після восьмиденного курсу внутрішньовенного уведення щурам із черепно-мозковою травмою, отримані результати свідчили про суттєве зростання його переваг відносно деескалації неврологічного дефіциту за шкалою C. P. McGrow, $з$ достовірною перевагою по відношенню до амантадину сульфату на $17 \%$ та магнію сульфату на $30 \%$.

3. Внутрішньовенне уведення адемолу у щурів із експериментальною черепно-мозковою травмою протягом восьми діб спостереження супроводжувалось достовірним покращенням мнестичних функцій за тестом умовної реакції пасивного уникнення, порівняно 3 розчином амантадину та магнію сульфату.

\section{Список літератури}

1. Бовт ЮВ, Кас ЮВ, Коршняк ВО, Сухоруков ВІ. Клінічні та патофізіологічні особливості гострої закритої черепно-мозкової травми, отриманої внаслідок вибухової хвилі. Український журнал "Чоловіче здоров'я, гендерна та психосоматична медицина”. 2016;2(04):12-18.

2. Shohami E, Biegon A. Novel approach to the role of NMDA receptors in traumatic brain injury. CNS Neurol Disord Drug Targets. 2014;13(4):567-573.

3. Карабань ИН. Применение блокатора глутаматных рецепторов амантадина в неврологии. Междунар. невролог. журнал. 2012;2:195-201.

4. Hammond FM, Sherer M, Malec JF, Zafonte RD, Dikmen S, Bogner J, et al. Amantadine Did Not Positively Impact Cognition in Chronic Traumatic Brain Injury: A Multi-Site, Randomized, Controlled Trial. J Neurotrauma. 2018;7:57-67.

5. Vink R, Cook NL, van den Heuvel C. Magnesium in acute and chronic brain injury: an update. Magnes Res. 2009;22(3):158-62

6. Lingam I, Robertson NJ. Magnesium as a Neuroprotective Agent: A Review of Its Use in the Fetus, Term Infant with Neonatal Encephalopathy, and the Adult Stroke Patient. Dev Neurosci. 2018;40(1):1-12.

7. Ходаківський ОА, Черешнюк ІЛ. Дослідження впливу похідного адамантану адемолу на фрагментацію ДНК ядер нейронів лобних часток кори за ішемії-реперфузії головного мозку у щурів. Український вісник психоневрології. 2013;1(74):26-28.

8. Ходаківський ОА. Вплив курсової експериментальної терапії адемолом (сполукою ЮК-1) на динаміку показників кислотно-лужної рівноваги в ішемізованому головному мозку. Вісн. морфології. 2010;4:787-90.

9. Ходаківський ОА. Вплив адемолу на стан оксидантно-антиоксидантного балансу в головному мозку щурів із моделлю гострої церебральної ішемії. Питання експериментальної та клінічної медицини. 2013;17:123-27.

10. McGrow CP. Experimental Cerebral Infarction Effects of Pentobarbital in Mongolian Gerbils. Arch. Neurol. 1977;34(6):334-36.

11. Лапач $\mathrm{CH}$, Чубенко АВ, Бабич ПН. Статистические методы в медико-биологических исследованиях с использованием Excel. Київ: МОРИОН; 2000. 320 с.

12. Ходаківський ОА. Патогенетичне обгрунтування доціль- ності використання нових похідних адамантану при експериментальній терапії гострої ішемії головного мозку та міокарда (експериментальне дослідження) [автореферат]. Одеса; 2014. 24 с.

\section{References}

1. Bovt YuV, Kas YuV, Korshniak VO, Sukhorukov VI. Klinichni ta patofiziolohichni osoblyvosti hostroi zakrytoi cherepno-mozkovoi travmy, otrymanoi vnaslidok vybukhovoi khvyli [Clinical and pathophysiological features of acute closed craniocerebral injury received as a result of an explosive wave]. Ukrainskyi zhurnal "Choloviche zdorovia, henderna ta psykhosomatychna medytsyna". 2016;2(04):12-18. (in Ukrainian).

2. Shohami E, Biegon A. Novel approach to the role of NMDA receptors in traumatic brain injury. CNS Neurol Disord Drug Targets. 2014;13(4):567-73.

3. Karaban' IN. Primenenie blokatora glutamatnyh receptorov amantadina $v$ nevrologii [The use of amantadine glutamate receptor blockers in neurology]. Mezhdunar. nevrolog. zhurnal. 2012;2:195-201. (In Russian).

4. Hammond FM, Sherer M, Malec JF, Zafonte RD, Dikmen S, Bogner J, et al. Amantadine Did Not Positively Impact Cognition in Chronic Traumatic Brain Injury: A Multi-Site, Randomized, Controlled Trial. J Neurotrauma. 2018;7:57-67.

5. Vink R, Cook NL, van den Heuvel C. Magnesium in acute and chronic brain injury: an update. Magnes Res. 2009;22(3):158-62.

6. Lingam I, Robertson NJ. Magnesium as a Neuroprotective Agent: A Review of Its Use in the Fetus, Term Infant with Neonatal Encephalopathy, and the Adult Stroke Patient. Dev Neurosci. 2018;40(1):1-12.

7. Khodakivskyi OA, Chereshniuk IL. Doslidzhennia vplyvu pokhidnoho adamantanu ademolu na frahmentatsiiu DNK yader neironiv lobnykh chastok kory za ishemii-reperfuzii holovnoho mozku u shchuriv [Investigation of the effect of adamantane adamel derivative on the fragmentation of DNA of coronuclear neuronal cortex for cerebral ischemia-reperfusion in rats]. Ukrainskyi visnyk psykhonevrolohii. 2013;1(74):2628. (in Ukrainian).

8. Khodakivskyi OA. Vplyv kursovoi eksperymentalnoi terapii ademolom (spolukoiu YuK-1) na dynamiku pokaznykiv kyslotno-luzhnoi rivnovahy $\mathrm{v}$ ishemizovanomu holovnomu moz$\mathrm{ku}$ [Influence of course experimental therapy with ademol (a compound of YK-1) on the dynamics of acid-base equilibrium indices in ischemic brain]. Visn. morfolohii. 2010;4:787-90. (in Ukrainian).

9. Khodakivskyi OA. Vplyv ademolu na stan oksydantnoantyoksydantnoho balansu $\mathrm{v}$ holovnomu mozku shchuriv iz modelliu hostroi tserebralnoi ishemii [Effect of ademole on the state of oxidative-antioxidant balance in the brain of rats with the model of acute cerebral ischemia]. Pytannia eksperymentalnoi ta klinichnoi medytsyny. 2013;17:123-27. (in Ukrainian).

10. McGrow CP. Experimental Cerebral Infarction Effects of Pentobarbital in Mongolian Gerbils. Arch. Neurol. 1977;34(6):334-36.

11. Lapach SN, Chubenko AV, Babych PN. Statistycheskie metodi $\mathrm{v}$ mediko-biolohycheskikh issledovaniiakh $\mathrm{s}$ ispolzovaniem Excel [Statistical methods in medical-biological research using Excel]. Kiev: MORION; 2000. 320 s. (in Russian).

12. Khodakivskyi OA. Patohenetychne obgruntuvannia dotsilnosti vykorystannia novykh pokhidnykh adamantanu pry eksperymentalnii terapii hostroi ishemii holovnoho mozku ta miokarda (eksperymentalne doslidzhennia) [avtoreferat] [Pathogenetic substantiation of expediency of the use of new adamantane derivatives in the experimental therapy of acute cerebral and myocardial ischemia (experimental research) [abstract]]. Odesa; 2014. 24 s. (in Ukrainian). 
Original research

\section{Відомості про авторів}

Семененко Святослав Ігорович — к.мед. н., доцент кафедри клінічної фармації та клінічної фармакології Вінницького національного медичного університету ім. М. І. Пирогова, м. Вінниця, Україна.

\section{Сведения об авторах}

Семененко Святослав Игоревич - к.мед. н., доцент кафедры клинической фармации и клинической фармакологии Винницкого национального медицинского университета им. Н. И. Пирогова, г. Винница, Украина

\section{Information about the author}

Semenenko S. I. - PhD in Medical Sciences, Associate Professor at the Department of Clinical Pharmacy and Clinical Pharmacology National Pirogov Memorial Medical University, Vinnytsia, Ukraine.

Надійила до редакції 02.07.2019

Рецензент - проф. Заморський I.I.

(C) C.I. Семененко, 2019 